\title{
SOCIAL MEDIA VS TRADITIONAL MEDIA AND THEIR IMPACT ON BRAND IMAGE COMMUNICATION ON INDIAN MILLENNIALS
}

\author{
Ajit Jain ${ }^{1}$ \\ ${ }^{1}$ Symbiosis Institute of Business Management (SIBM), Symbiosis International (Deemed University) (SIU), \\ Electronics City, Hosur Road, Bengaluru, Karnataka, India
}

\begin{abstract}
The study focuses on examining which form of marketing out of the age-old Traditional Media or the latest Social Media Marketing has a greater impact on the consumer and which form, can communicate the brand image in a better way. The study focuses on finding answers to questions like what are the new platforms to reach out to targeted consumers, Reasons for which customers follow a brand on social media? etc. Concepts related to the brand image, traditional media, social media marketing, and lastly branding on social media platforms are introduced and examined in the paper. The experimental part of the study consists of a quantitative survey on Indian millennials and generation $\mathbf{Z}$ customers, i.e. in the age group of 15-30 years. The results imply that in general social media marketing methods are more effective and can communicate brand image in a better way than that of traditional media. Also, today's young generation is more attracted to the brands having a strong social media presence.
\end{abstract}

Keyword: social media marketing, internet marketing, advertising, traditional media marketing, conventional marketing, brand image, digital marketing, millennials

\section{Introduction}

Brand image is the perception of the brand in the mind of the consumer or the way he thinks of a brand. The brand image takes time to develop and can be defined as an aggregate of beliefs, ideas, and impressions that a customer holds regarding that brand. The image formation can happen in several ways majorly through interactions, experiences, word of mouth, or advertisements in present times.

Building and maintaining brand image are some of the central themes of research for marketers for a very long time. Marketers have implemented various means to build and maintain the brand image of their customers. One recent development in this area is social media marketing. Marketers have utilized various means to communicate the brand image in their customer's mind by including brand elements, classical marketing mix variables, and new methods of marketing such as events, sponsorships, one-to-one marketing activities, and Internet marketing and social media marketing as the latest (Erdogmus, İ. E., \& Cicek, M. (2012)).

This study aims to identify whether social media marketing helps in communicating brand image better than traditional marketing or not to consumers. The scope of the study consists of Indian customers who follow at least one brand on social media and then the primary or firsthand data will be collected through a structured questionnaire.

\section{Theoretical Background}

Traditional marketing refers to conventional marketing strategies which have been used since the idea of advertising or marketing came into existence. This is a rather broad category, which incorporates many forms of advertising and marketing that we see and hear every day. Traditional marketing majorly includes Newspapers, Flyers, Magazines, Radio, Television, and Billboards advertising for brand promotion. Generally, traditional marketing strategies can be divided into four categories: print, broadcast, direct mail, and telephone. Print marketing is the oldest form of traditional marketing simply defined as advertising in paper form; this strategy has been in use since ancient times.

While on the other hand, Social media marketing or SMM is the new age marketing method of the global realm. With the Internet finding its application and benefit in every area of modern-day life, marketing has not only succeeded in raising awareness or supporting products through it but also give them a global platform to reach a wider customer base and connect with your audience to build your brand, increase sales, and drive website traffic. This includes posting quality content on your social media pages about your brand, listening to and engaging your fans, reviewing your performances, and running advertisements on social media. The major social media platforms at present are Facebook, Instagram, Twitter, LinkedIn, Pinterest, YouTube, and Snapchat.

Currently, the development of the internet and increased usage of mobile devices such as smartphones, tablets, laptops, etc. have contributed greatly to the availability of various content online, the content that previously used to be available only on mainstream media outlets such as print media, radio, and television. This, in turn, has resulted in a growing trend in 
online content consumption and collaboration among members of the online community.

According to researcher Shama Kabani over half of all consumers said that they had already purchased something - or switched to another brand or retailer - because of a recommendation they received through a social media platform. The questions that puzzle the minds of marketing executives include: the importance and effect of an investment in social media on revenue generation, the knowledge of easing control of the brand and additional exposure it creates, the accuracy and measurability of the social media activities (Nekatibeb, T. (2012)).

According to theory: A large portion of media research is concerned with the question of whether or not media exposure can influence an individual's attitudes or behaviors. However, the prior circumstances of a person can contribute to selective exposure or attention to particular media content. This selective exposure or attention to media contents may then reinforce the attitudes or behavioral changes.

Experts use several theories to explain the influence of Social Media on an individual's attitude or behavior. Some of these theories are:

- $\quad$ Social Cognitive Theory

- Theory of Social Presence and

- The Media Richness Theory

Social cognitive theory (Bandura, 1986, 2001, 2002) is one of the most influential and typically stated theories in the area of research into mass communication (Bryant \& Miron, 2004). It demonstrates the experiential learning of human behaviors and their specific capacity. The theory also suggests a theoretical framework for identifying subsequent processes that will direct observational analysis, including interest, retention, development, and motivational methods.

The Media Richness Theory (Daft \& Lengel, 1986) states that various media have a varying degree of richness, based on the ability to communicate numerous verbal and nonverbal signals, the ability to provide direct input, the use of natural language, and the existence of personal attention. Therefore, some media are more efficient in addressing ambiguity and confusion than others.

Marketing in present times is more strategic, more productive, and, in exchange, cheaper.

You may also decide the digital marketing ROI which is much more useful for investing in social media. Brands are now days targeting their ideal customers directly, rather than searching for a large market to bombard their advertising. These brands are building relationships with these ideal buyers through increasingly powerful marketing strategies that foster confidence in their product or service. The internet added to these conventional networks, which gave marketers more opportunities and changed the marketing process by offering resources that were not possible by the use of conventional marketing instruments (Varfan, M., \& Shima, A. (2008)). Every communication channel has its importance but the internet as a channel has developed and constantly growing and received a lot of attention from everyone (Ivanov, A. E. (2012)).

\section{Research Aim \& Importance}

This paper aims to compare traditional marketing methods like TV, newspaper, print media, etc. and social media marketing methods like Facebook, Instagram ads, etc. With the help of these online media networks, these approaches help individuals promote their blogs, products, or services and tap into a much wider audience that may not have been accessible via conventional channels. More precisely, the paper aims to examine the impact of social media marketing on the millennial-age consumers' brand image and brand loyalty, given that the topic is attracting rising attention from marketing academics and practitioners.

We choose India as the context of research because according to a report by Nielsen and Internet and Mobile Association of India (IAMAI) India has attained a $50 \%$ internet penetration rate, which was around $27 \%$ only 5 years ago. Market research agency Kantar IMRB report says that with more than 560 million internet users and estimated to be over 650 million by 2023, India becomes the second-largest online marketplace in the world after China as per Mary Meeker's 2019 Internet Trends Report. 


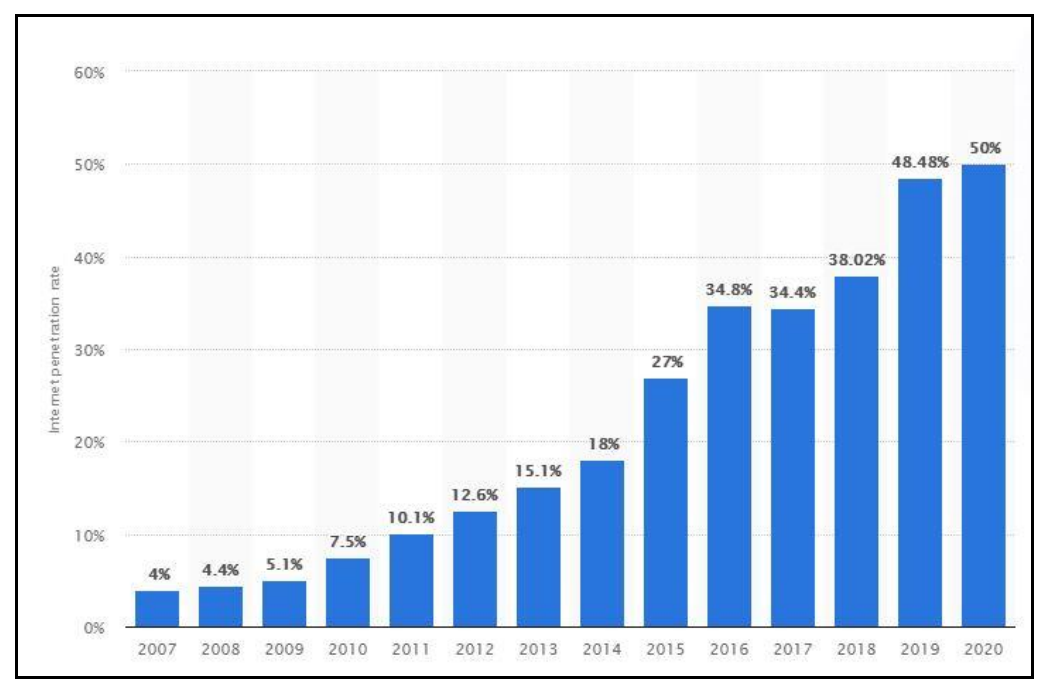

Fig.1 Internet penetration rate in India from 2007-2020

Sources: India Brand Equity Foundation; Aranca; The Economic Times; Livemint; DataReportal; TRAI

It is also worth noting that the majority of internet users of India fall in the range of 20 to 29 years classified as millennials. Besides, there is a large gap between male and female internet users in the country. One area wherein India shares similar attributes of other global internet users is its affection for social media. In India, predicted social network users would be almost 450 million by 2023, a symbolic increase from 2018 when this figure was about 326 million.
According to datareportal.com, Facebook was the most favored social platform in the country with nearly 280 million active Facebook users, and as of 2020, India ranks $1^{\text {st }} \underline{\text { in terms }}$ of Facebook users in the world. Facebook strives a $25 \%$ penetration rate among total internet users of India, which is ranked no. 1 with 241 million active users among all the countries. Given these data and statistics, India offers a credible platform to examine social media marketing developments and come up with some extensive results.

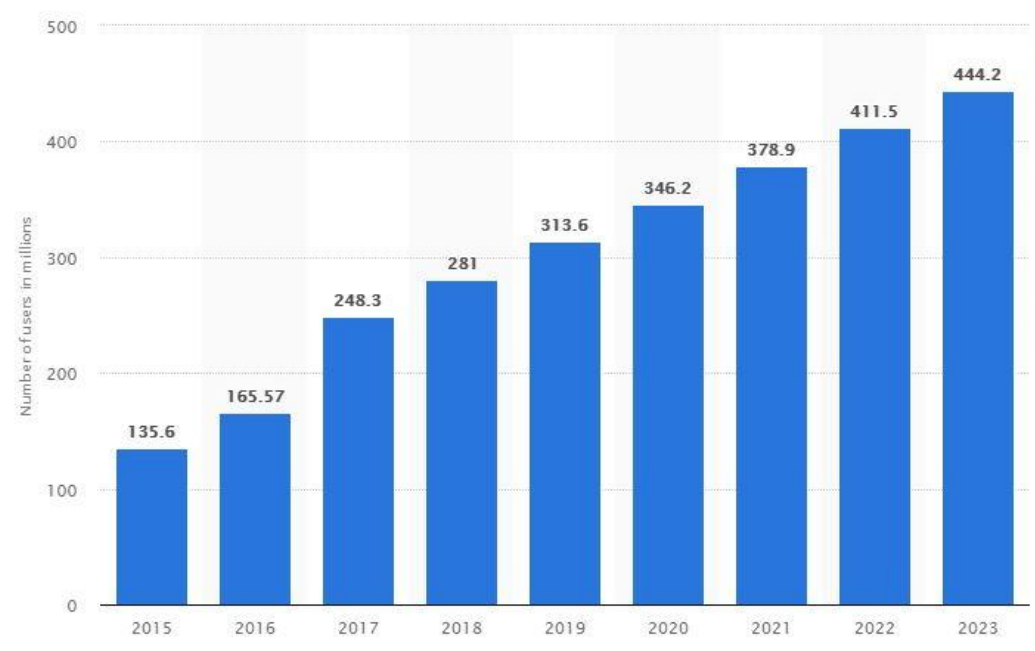

Fig.2 No. of Facebook users over the years (in millions)

Sources: Statista; Statista Digital Market Outlook

\section{Research Objective}

The objective of this study is to analyze if Social Media Marketing helps in communicating brand image in a better way than Traditional Marketing techniques in Indian millennials or not.

\section{Review of Literature}

In their research, Bruhn et al. (2012) have identified the proportionate impact of social media brand communication on brand equity relative to conventional media. It aims to investigate whether both communication methods have an effect on the customer-based brand value or which of the two has been more impactful; to compare the impact sizes of these two communication contraptions and to discern the effects of corporate and consumer-generated social media contact. The survey results showed that both of these types have a major effect on brand equity. On one side where Traditional media is more responsible for brand awareness, social media has an edge on creating a strong brand image.

Jokinen, T. (2016) explained in his thesis by examining how branding can be done by utilizing social media, what factors to be considered 
when doing it, and to analyze the effect of social media on the brand image as compared to conventional media. The findings indicate that in general social media and traditional media methods have the same level of impact on brand image. However, there can be a few variations based on the targeted customer segment. Results indicate that demographics and social media utilization have a remarkable association with purchasers' perceptions of the effect of social media on brand image.

Hanaysha, J (2016) wrote this paper to assess the effect social media advertisements have on brand equity in Malaysia's fastfood restaurant industry. Research results showed that social media advertisements have a major positive effect on brand equity and its dimensions like brand image, brand loyalty, etc. Hence, restaurant managers and owners must focus on marketing on various social platforms to build strong connections with customers by informing them about various products and services easily and cost-effectively. This type of relationship with customers helps the companies to understand customer's desires and expectancies and would able to solve their issues on time.

According to Bayo-Moriones \& Lera-Lo' pez from a customer's viewpoint, data communication technologies offer many benefits which include ease, performance, wider product range, aggressive pricing, reduced cost, product diversity, etc. Online networking platforms tend to increase these benefits, as customers can now talk freely and more proactively. Going with the trends if most of the consumers especially the millennials and gen $\mathrm{Z}$ engage with social media, then firms have to make their presence on social media as well. Previously companies used traditional methods like telemarketing, radio, etc. to disseminate info about their products or services and the internet was used mainly to display messages about marketing. If corporations now want to develop relationships with customers, then another Webbased mechanism is required.

In particular, organizations can attempt to identify and extend digital relationships using promotional strategies that emphasize the co-creation of material and context in content. This forces firms to use social media sites to embrace a digital presence. In response, firms wanting to connect with their clients can do so by sharing participatory information on the Internet. This kind of approach would permit not only more impactful marketing strategies but also a completely new partnership paradigm.

According to a survey conducted on managers, $56 \%$ of them rated external competitive pressure as critical or extremely important and it plays a vital position in a firm's preference to use digital technology for marketing purposes. For example, digital media offers many benefits to businesses (Ainscough \& Luckett, 1996); arguing that the Internet can be used for marketing, market research, internet advertising, and customer service. Other scholars argue that the Internet can help with brand building, facilitating customer WOM feedback, viral marketing, and crowdsourcing (Whitla, 2009).

Summary of the results of the study are in the table below as Benefit of Digital Presence:

\begin{tabular}{|l|l|}
\hline Type of Benefit & $\%$ \\
\hline $\begin{array}{l}\text { Improvement in information gathering and } \\
\text { feedback }\end{array}$ & $87 \%$ \\
\hline User-friendly tool & $85 \%$ \\
\hline Increase in knowledge & $85 \%$ \\
\hline Internal and external relationships promotion & $82 \%$ \\
\hline Support in decision-making process & $60 \%$ \\
\hline Increase in productivity & $58 \%$ \\
\hline Better outcome measurement & $53 \%$ \\
\hline
\end{tabular}

Note: $\mathrm{N}=170$

a Percentage of respondents rating 4 or 5 on a 1-5 scale where 5 = extremely important.

Several rewards of digital marketing praised by respondents are easefulness, its capacity to increase knowledge, and the promotion of the firm's in-house and outer relationships. Results show that advertisement is a major factor in internet marketing. However, digital marketing is not constrained simply to the content material of the message it additionally extends to links with clients and depicts an effective tool for building, reinforcing, and retaining brand image (Tiago, M. T. P. M. B., \& Veríssimo, J. M. C. (2014)).

In the study done by Jokinen, T. (2016) it is stated that advertising in conventional media includes many demanding situations such as a large number of unimportant contacts, excessive charges, and the diminishing impact of changes in media habits and the digital transition (Karjaluoto 2010, 108109). It is also mentioned that conventional media relies on a one-to-many model when creating a brand message, and is conveyed as one-way communication to a mass target audience. In comparison to social media, this isn't always as successful in building interaction or increasing awareness (Hausman, 2014).

Social media is real-time and multidirectional so that customers can engage directly with the brands and with each other making it an amazing platform for building the relationship and advertising through word-of-mouth. According to Celaya $(2008,85-88)$, when organizations use these social media services in their marketing, their primary goal is to boost sales and improve customer interaction. According to Pozin $(2014,2)$, it's also critical for "branding, acquisition, and retention."

Some critical factors in branding and marketing on social media are that the customer has full control over the content he 
views, like, or share. The marketing efforts in digital media are inexpensive, noticeably measurable, and targeted as compared to conventional media. It can be proclaimed that traditional mass media is stronger in growing brand awareness as compared to social media because of massive mass media campaigns. Though the downside of branding through mass media is the lack of precise target audiences and measurability, and hence few of the consumers reached by this method are not a part of the selected consumer groups. Only Campaigns that reach a suitable target audience are successful in the long run in increasing brand awareness (Jokinen, T. (2016)).

A literature review conducted by Adzharuddin (2012) on the present-day trend of traditional media marketing versus new social media marketing found out that internet advertising lets in for something more that television, radio, or newspaper might not be able to provide ever. It focused on interactivity and allows bilateral communication; it also highlighted the point that today's consumers are active players as opposed to passive receivers. Moreover, it presents marketers to cut through the clutter in traditional marketing activities of TV/Radio and newspaper ads. While the usage of the internet or social media as advertising gear has furnished businesses with cheap, measurable, and immediate assets for their targeted audience.

Due to these advantages, Internet marketing campaigns saw an increase of $14.3 \%$ in spending budget on the contrary traditional marketing campaigns saw a huge decrease in spending of $161.5 \%$ (The CMO Survey, 2012). Further to this, print newspaper commercials sales have reduced by nearly two-thirds in the past two decades.

Today companies' presence on social media is as necessary as their websites or contact numbers. With today's fast-paced world, social media can fulfill customer's demand to access products anytime, and firms must upward thrust to meet this demand. According to a McKinsey Report (2012), it is shown that companies are "networked" and adopted the latest techniques for reaching out to their clients are far ahead than other players in terms of making a profit and capturing the market. Social media marketing has emerged as the latest way for firms to build brand image and awareness for newer generations. With contemporary studies pointing to Facebook and other social platforms like Instagram and Snapchat being just as effective as the traditional ways of TV and radio ads, social media marketing still has an edge in having an overall less expensive and more targeted advertising strategy (Cowden, A. G. (2014)).

This study focuses on how the rural business can attract people of young age using the web and social media platforms as these days' major youth are available on social media. It is also evident that the conventional methods of marketing unable to make an impact in the case of small businesses on the contrary advertising through the internet emerged as an important asset for the tourism industry. According to the study, the marketing and advertising industry had to deal with the increase of social media customers and mostly the millennials and centennials, the generation having the most purchasing power. Bennett (2014) claims in his research that around 75 percent of customers make their buying decisions based totally on social media and the maximum of these are millennials which is most connected and active on social media. Studies found out the promising relationship between social media influencers with buying purposes (Lim et al., 2017). Younger generations tend to acquire sense from those Social media influencers whom they like or admire (Chatzigeorgiou, C. (2017)).

According to research done by D'silva, B, Bhuptani, Menon, and D'Silva, S. (2011), some particular features of social media platforms like Facebook, Twitter, Instagram, etc. have created massive impulse on the brand communication. Social media is extensively utilized as an advertising and marketing tool in creating brand awareness and brand image among the customers. It is the least expensive tool for getting information. Therefore, most of the customers rely on it to evaluate and examine brands and products. Marketers have found out the importance of social media platforms as an important factor of IMC (Integrated Marketing Communications). It also encourages the continuous exchange of info with customers about their likes and preferences and troubles faced with the product. This facilitates businesses to take corrective measures on time and change their products that suit the user's needs. Social media can further be used for new product launch and finally results in greater revenue and helps in capturing the larger market share.

Insights generated from the study done by Suki and Sasmita on Brand Loyalty and social media implies that respondents are most satisfied with product/brand that appeared frequently on social media" and "they would recommend particular products/brands to others through the social media" and "will not switch to another product/brand that appeared in the social media next time". In another part of this research related to Brand awareness, the findings are, customers are more aware of the particular brand that they have come across on social media websites. They are also able to recognize any particular brand whose ads they have watched on social platforms as compared to other brands that are not on social media or not followed by him/her.

Duffett, R. G. (2017) explains in his research that at present times, social media has started to replace traditional media's influence and enduring role on young purchasers. Nowadays for marketing and promotion of new products to young customers, marketers increased their dependency on social and mobile ICT 
channels. Additionally, the entertaining content would force young users to share it among their friends. This considerable feature popularly known as word-of-mouth (WOM), can be considered as the important feature of social media marketing communications in the coming future (Yaakop et al., 2013). Teenagers who are ignorant of the digital world are also targeted by continuously streaming relevant content by marketers on their smartphones and other devices (Barker et al., 2013; Williams, 2015). Bridges et al (2009) also examined that for a greater positive impact in buying behavior the ads and commercials should show for a longer duration. Zoomers, who are more tech-savvy have displayed the maximum positive sentiments toward advertising and marketing communications.

\section{Research Gap Identification}

Traditional marketing is the kind of marketing which is in the market for ages. It uses the marketing methods that can be used without the internet. These methods have been around for decades and are typically used less often now. While as not all the population has access to the internet or not everyone is tech-savvy, so they have their strengths and hence still popular in today's age. On the other side, Social Media Marketing or Digital Marketing is the opposite of traditional marketing. Its strategies evolve quickly because of trends and new technology and require the use of the internet or smartphones. They have not been around as long as traditional methods, however, they certainly pack a punch.

Digital grew by $37 \%$, adding $\$ 613$ million to Adex, to attain a figure of $\$ 2.2$ billion in 2019. Digital advertising contains the spending on video ads across all digital formats starting from social media and over the top (OTT) platforms to YouTube, gaming, news, and other websites. The video format has the maximum share as of today and it continues to grow at the fastest rate among all digital advertising formats. As ad-spend gets increasingly redirected towards digital media from traditional formats the digital advertising market is set to become the largest among all media - TV, print, radio, out of home- at $\$ 5.89$ billion by FY23.

Therefore, in this study, we are going to find out which of these two types of marketing is better in communicating brand image in the customer's mind. The decades-old Traditional marketing serving every group of the population or the latest trending Social Media Marketing targeting a small group of the population as compared to the earlier one.

\section{Data Collection and Methodology}

\section{Dataset:}

Primary or firsthand data is collected from Indian millennial consumers with the help of an online-structured questionnaire from the sample consisting of 151 people. Some filter questions are included to make sure that the respondents are qualified for research. One question asked whether the respondent is on social media or not. Another question was if he is aware of social media marketing or not if yes then whether the person followed at least one brand on any social media platform. The sample consisted of around $64 \%$ male and $36 \%$ female and the average age of the sample was around 25

years.

After the sample questionnaire was completed and submitted, statistical analysis software was used to handle the responses and finding the patterns. The research addressed the gap set out in the research objective by recognizing the patterns and consumer behavior towards the two forms of marketing.

\section{Methodology}

Multiple Chi-square tests: A Chi-Square test is a test of statistical significance for categorical variables. It is used to evaluate the hypothesis of how results are distributed in various categories. This is a non-parametric test and is usually used to assess the statistical difference between the value observed and the predicted. In this case, we have categorical data for one independent variable and we would like to verify if the data distribution is similar or different from that of the predicted distribution between the following factors:

1. Gender and various forms of Marketing

2. Social Media Awareness and various forms of Marketing

3. Social Media Awareness and Preferred Platform for Advertising

Descriptive Statistics: Descriptive statistics are brief descriptive coefficients summarising a given sample of data that can either be a representation of the entire population or a subset of it. All descriptive statistics are either measures of the central tendency (including mean, median, and mode), or measures of variability (including standard deviation), also known as dispersion measurements. Descriptive statistics purpose is to represent hard-to-grasp quantitative observations with a broad range of data into bite-sized explanations in the form of tables, graphs, charts, etc. to more readily understand the significance of the analyzed data. Using it, the following variables were analyzed:

1. Effectiveness of Marketing on various Channels

2. Reasons to follow a Brand on Social Media

3. Effectiveness of Marketing on various Social Platforms

Analysis Tools:

- IBM SPSS

- MS Excel

\section{Analysis of Data \& Findings}

A structured online survey of 13 questions consisting of demographic as well as theme related to the research is done for the Quantitative research of this paper. The survey was 
designed for a targeted customer segment i.e. generation $\mathrm{Y}$ or millennials and generation $\mathrm{Z}$ or centennials. The main purpose of incorporating the survey was to analyze the impact of brand image and communication when done by traditional methods and by social media channels and to find out the current and future trends in marketing. A total of 151 respondents had

\begin{tabular}{|l|l|l|}
\hline Gender & Frequency & Percentage \\
\hline Male & 95 & $62.9 \%$ \\
\hline Female & 56 & $37.1 \%$ \\
\hline
\end{tabular}

\begin{tabular}{|l|l|l|}
\hline Age & Frequency & Percentage \\
\hline Under 20 & 03 & $2.0 \%$ \\
\hline $20-30$ & 146 & $96.7 \%$ \\
\hline $30-40$ & 02 & $1.3 \%$ \\
\hline Above 40 & 00 & $0.0 \%$ \\
\hline
\end{tabular}

\section{Analysis}

\section{Hypothesis test between Gender and various forms of Marketing}

filled the questionnaire and the responses were analyzed by performing chi-square tests and making different charts to come to certain conclusions.

\section{Demographic Details}

Null Hypothesis (Ho): The chosen effective form of marketing is independent of Gender.

Alternate Hypothesis (Ha): The chosen effective form of marketing is dependent on Gender.

Gender * various forms of Marketing Cross tabulation

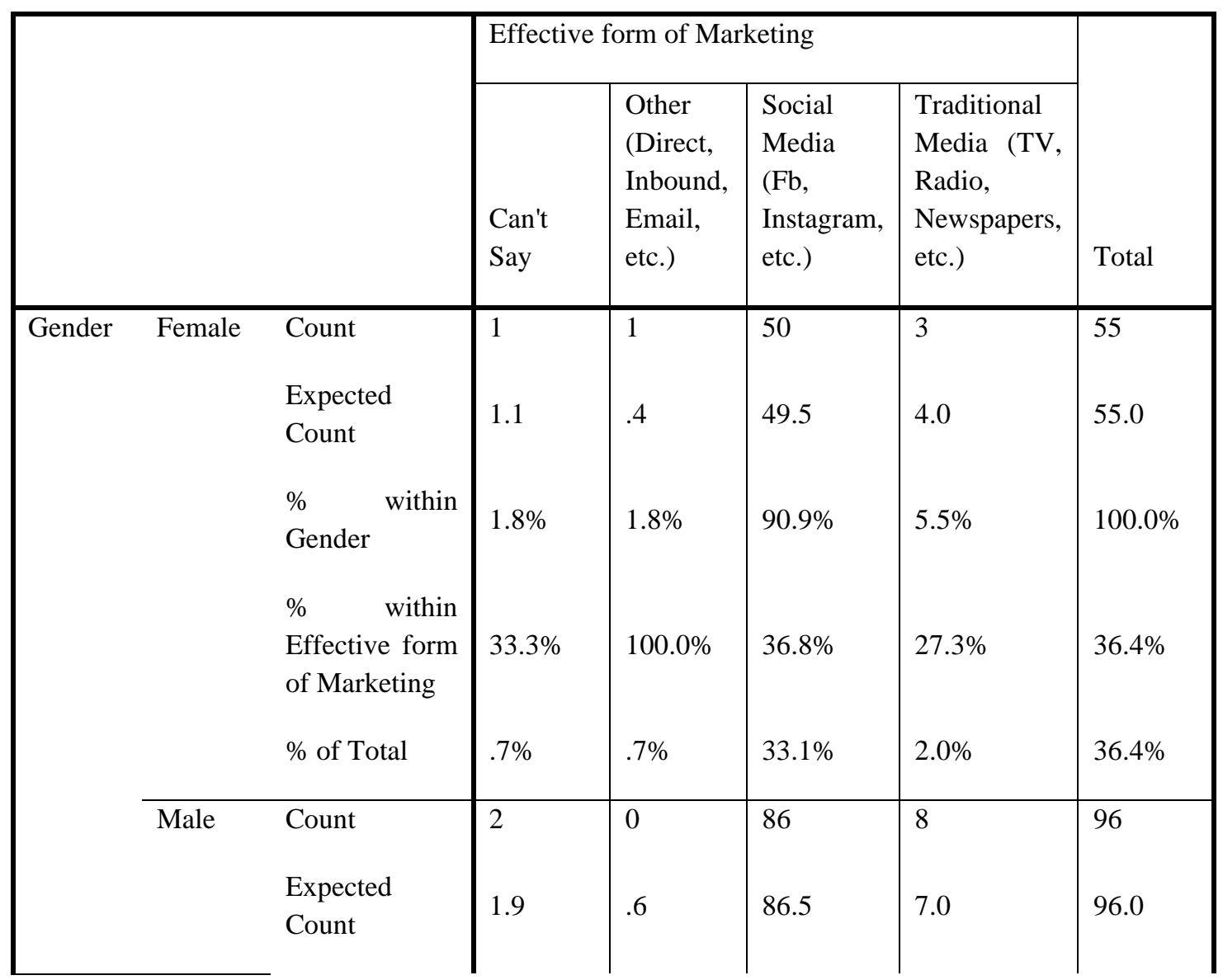




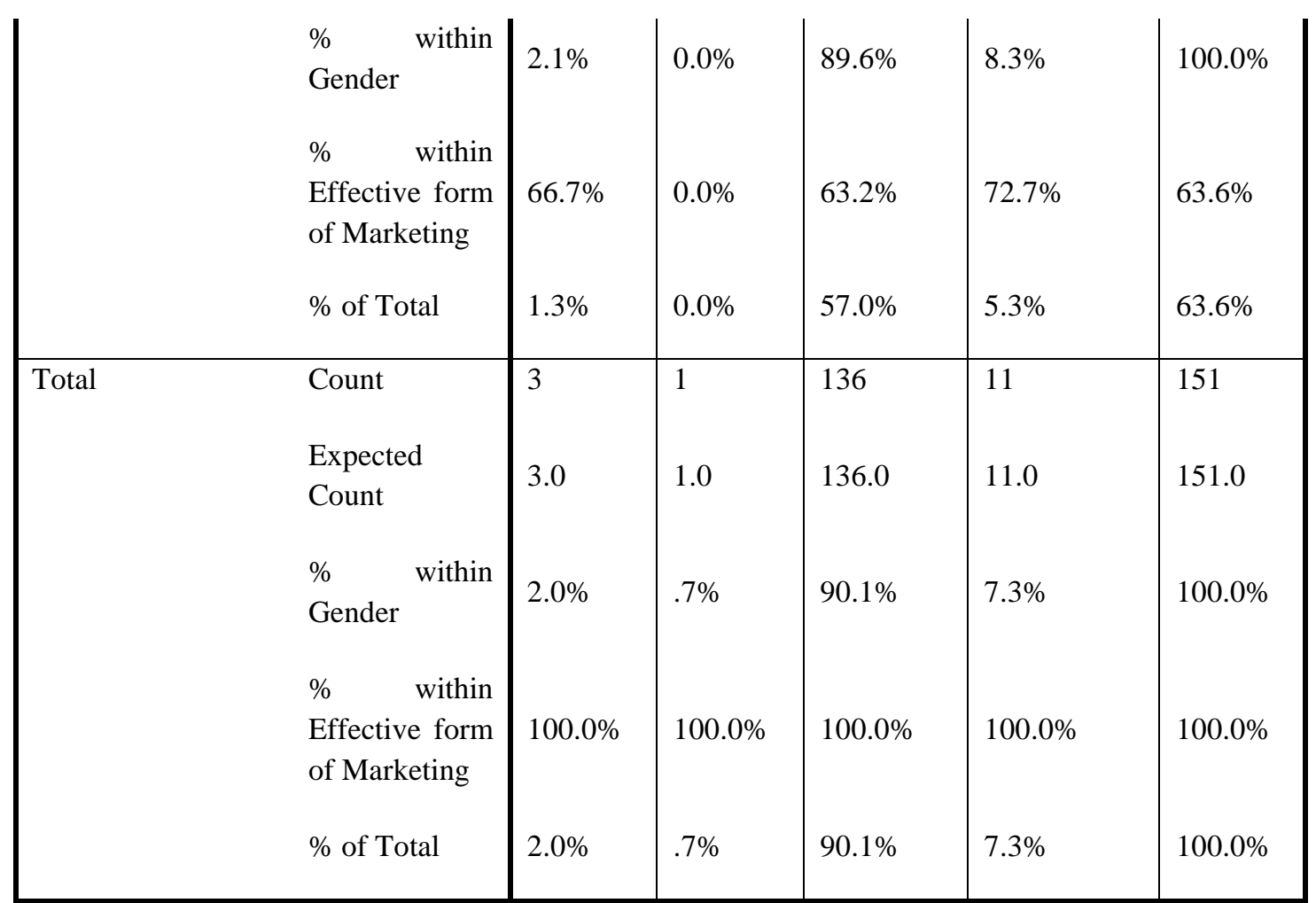

Chi-Square Tests

\begin{tabular}{|l|l|l|l|}
\hline & & & $\begin{array}{l}\text { Asymptotic } \\
\text { Significance (2- } \\
\text { sided) }\end{array}$ \\
\hline $\begin{array}{l}\text { Pearson Chi- } \\
\text { Square }\end{array}$ & $2.162^{\mathrm{a}}$ & 3 & .539 \\
$\begin{array}{l}\text { Likelihood } \\
\text { Ratio }\end{array}$ & 2.455 & 3 & .484 \\
$\begin{array}{l}\mathrm{N} \text { of Valid } \\
\text { Cases }\end{array}$ & 151 & & \\
\hline
\end{tabular}

In the above first table, we have done a cross-tabulation between gender and effective forms of marketing. Out of a total of 151 respondents, 55 are female and 96 are male. When asked about the more effective form of marketing, 136 responded in favor of SMM while only 12 responses chose traditional media channels and other methods.

After the results of the cross-tabulation, the statistical significance between variables is tested using the chi-square test which gave the Pearson chi-square value as 0.539 which is greater than 0.05, hence we accept the Null Hypothesis Ho i.e. Chosen effective form of marketing is independent of gender.

\section{Hypothesis test between Social Media Marketing Awareness and various forms of Marketing}

Null Hypothesis (Ho): The chosen effective form of marketing is independent on Social media marketing awareness.

Alternate Hypothesis (Ha): The chosen effective form of marketing is dependent on Social media marketing awareness.

SMM Awareness * Effective form of Marketing Cross tabulation 


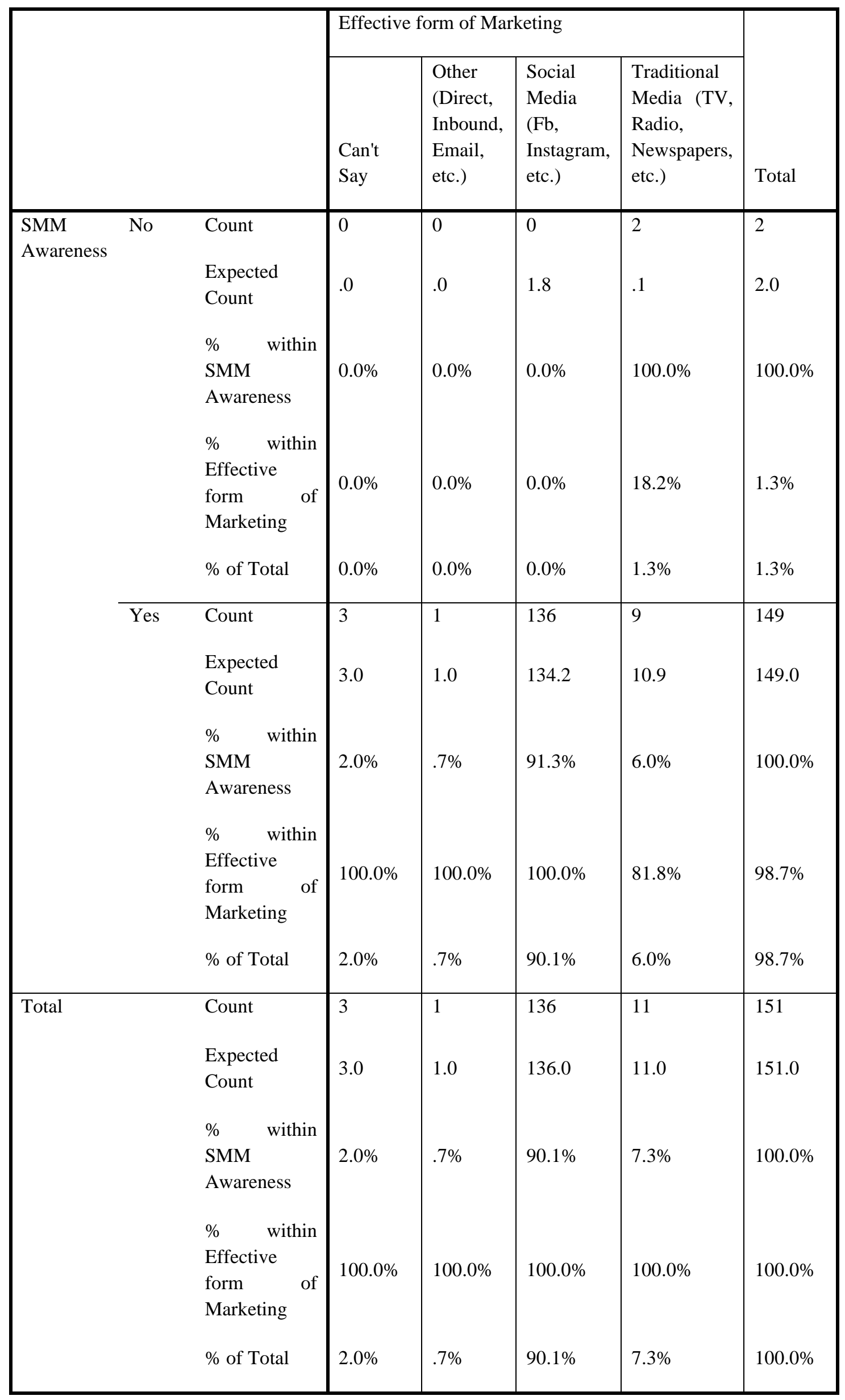


Chi-Square Tests

\begin{tabular}{|l|l|l|l|}
\hline & Value & Df & $\begin{array}{l}\text { Asymptotic } \\
\text { Significance } \\
\text { (2-sided) }\end{array}$ \\
\hline Pearson Chi-Square & $25.796^{\mathrm{a}}$ & 3 & .000 \\
$\mathrm{~N}$ of Valid Cases & 151 & 3 & .013 \\
\hline
\end{tabular}

In the above cross-tabulation between social media marketing awareness and effective form of marketing. When asked about the SMM awareness and effective form of marketing, 149 out of 151 responses are aware of the social media marketing and $136(91.2 \%)$ of them responded in favor of SMM while the rest $8.72 \%$ responded in favor of traditional media marketing or other methods.

After the results of the cross-tabulation, the statistical significance between variables is tested using the chi-square test which gave the Pearson chi-square value as 0.000 which is less than 0.05, hence we accept the Alternate Hypothesis Ha i.e. Chosen effective form of marketing is dependent on SMM awareness.

\section{Hypothesis test between Social Media Marketing Awareness and Preferred Platform for Advertising}

Null Hypothesis (Ho): Preferred platform of Marketing is independent of SMM awareness.

Alternate Hypothesis (Ha): Preferred platform of Marketing is dependent on SMM awareness.

SMM Awareness * Preferred Platform of Advertising Cross tabulation

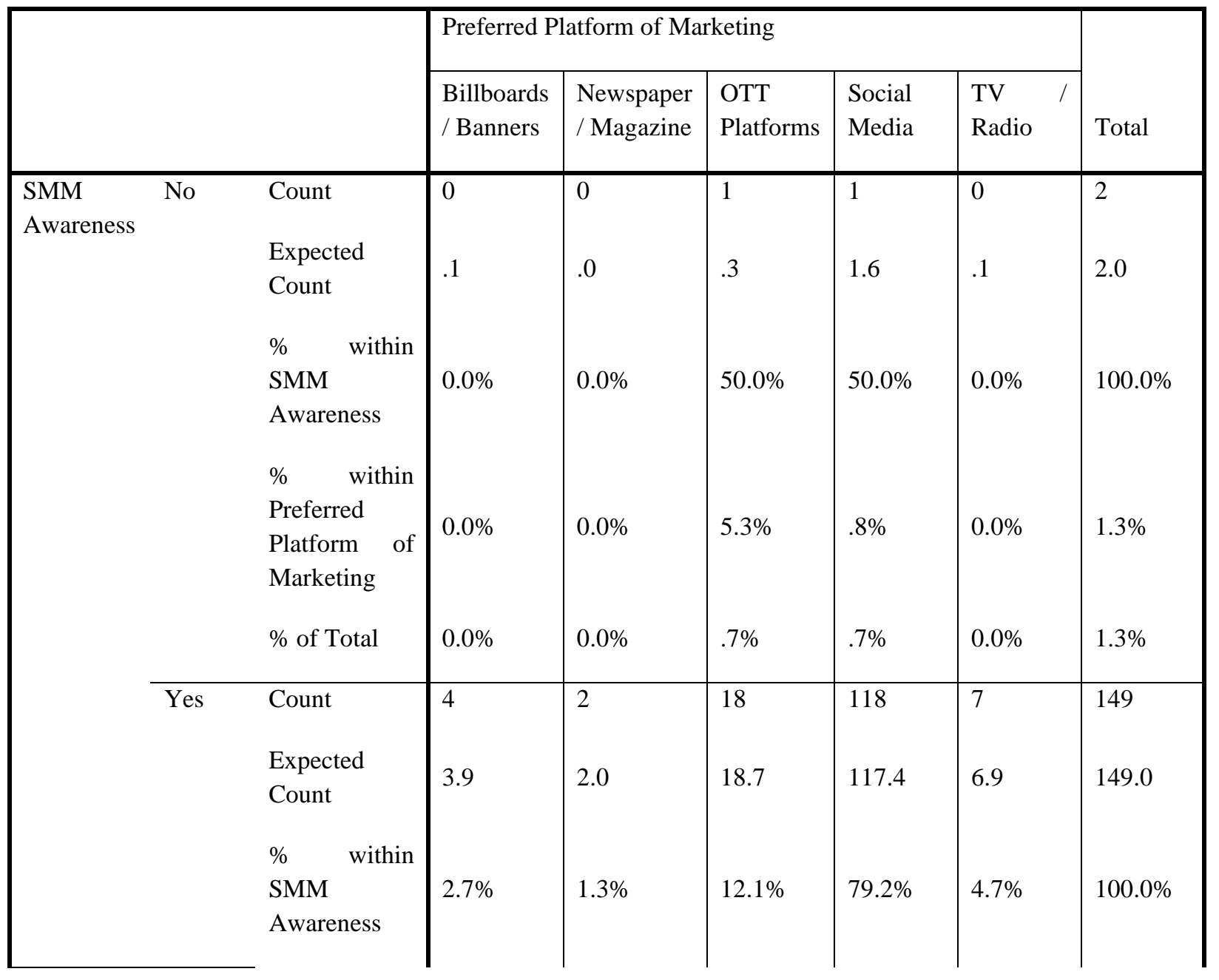




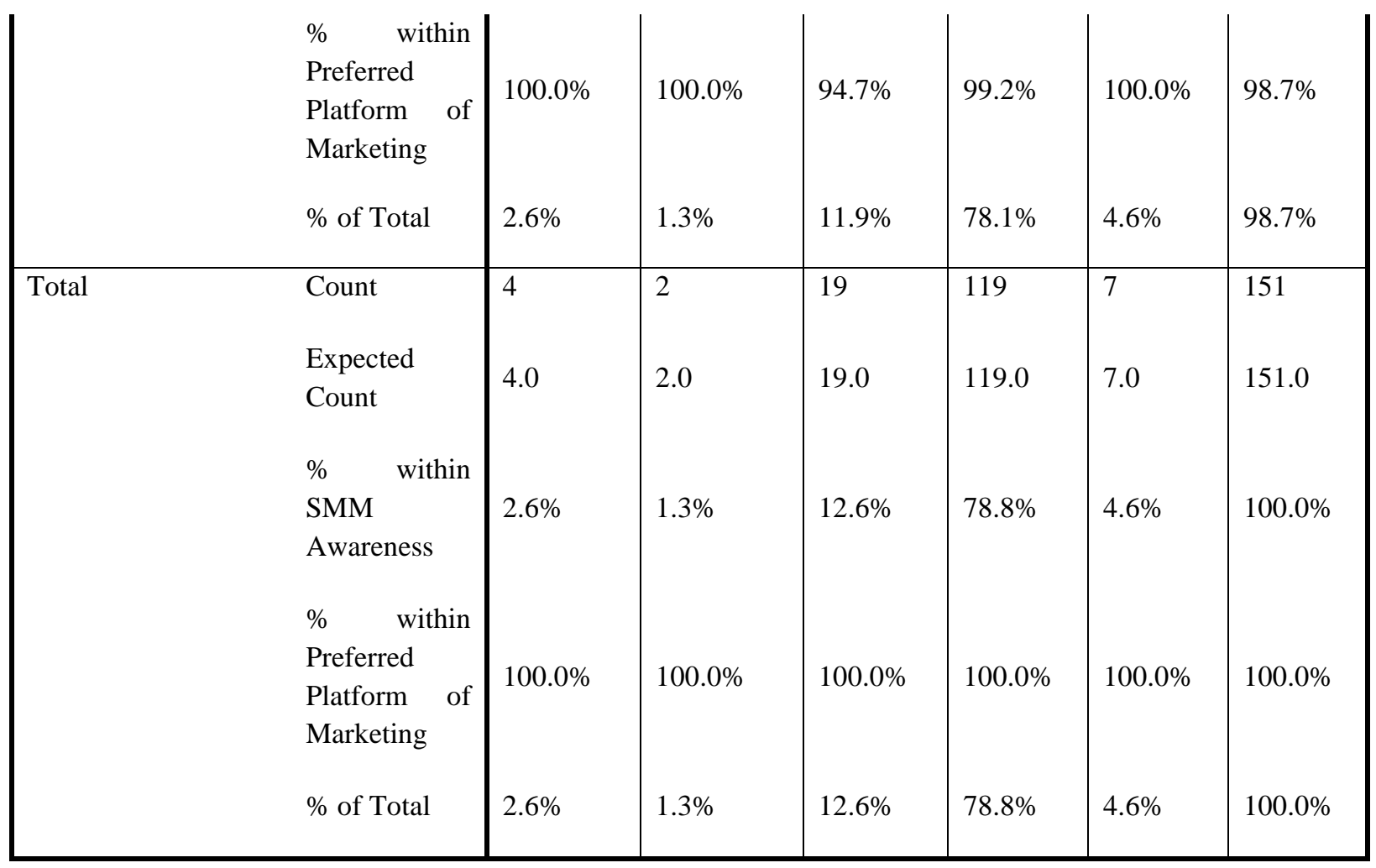

Chi-Square Tests

\begin{tabular}{|l|l|l|l|}
\hline & Value & Df & $\begin{array}{l}\text { Asymptotic } \\
\text { Significance } \\
\text { (2-sided) }\end{array}$ \\
\hline Pearson Chi-Square & $2.643^{\mathrm{a}}$ & 4 & .619 \\
Likelihood Ratio & 1.885 & 4 & .757 \\
\hline
\end{tabular}

i.e. Preferred platform of Marketing is independent on SMM

In the above cross-tabulation between SMM awareness and the preferred platform for marketing, when asked about it then 118 of the 149 responses who are aware of social media marketing chose social media sites as their preferred platform to advertise while 18 of them chose OTT platforms and the rest 13 chooses traditional media like TV/Radio, print media, and Billboards as the best to advertise.

After the results of the cross-tabulation, the statistical significance between variables is tested using the chi-square test which gave the Pearson chi-square value as 0.619 which is greater than 0.05, hence we accept the Null Hypothesis Ho

\section{Descriptive Statistics}

1. Effectiveness of Marketing on various Channels

\begin{tabular}{|c|c|c|c|c|c|c|}
\hline & $\mathrm{N}$ & Minimum & Maximum & Mean & $\begin{array}{l}\text { Std. } \\
\text { Deviation }\end{array}$ & Variance \\
\hline $\begin{array}{l}\text { TV/Radio } \\
\text { Effectiveness }\end{array}$ & 132 & 1.0 & 4.0 & 2.811 & .9972 & .994 \\
\hline
\end{tabular}




\begin{tabular}{|c|c|c|c|c|c|c|}
\hline $\begin{array}{l}\text { Print Media \& } \\
\text { Billboards } \\
\text { Effectiveness }\end{array}$ & 133 & 1.0 & 4.0 & 2.797 & .7954 & .633 \\
\hline $\begin{array}{l}\text { Social Media Sites } \\
\text { Effectiveness }\end{array}$ & 135 & 1.0 & 4.0 & 3.519 & .6895 & .475 \\
\hline $\begin{array}{l}\text { Influencers } \\
\text { Effectiveness }\end{array}$ & 134 & 1.0 & 4.0 & 3.022 & .8449 & .714 \\
\hline Valid N (listwise) & 132 & & & & & \\
\hline
\end{tabular}

From the collected responses, when asked about the effectiveness of advertising on various channels, respondents ranked social networking sites as the most effective with an average of 3.519 followed by influencers with an average of 3.022 on a scale of 1 to 5 (1-least effective, 5- most effective).

2. Reasons to follow a Brand on Social Media

\begin{tabular}{|l|l|l|l|l|l|l|}
\hline & $\mathrm{N}$ & Minimum & Maximum & Mean & $\begin{array}{l}\text { Std. } \\
\text { Deviation }\end{array}$ & Variance \\
\hline Advertisements & 130 & 1.0 & 5.0 & 3.608 & 1.1309 & 1.279 \\
Product Quality & 129 & 1.0 & 5.0 & 3.992 & .9802 & .961 \\
$\begin{array}{l}\text { Logo, jingles } \& \\
\text { Tagline }\end{array}$ & 130 & 1.0 & 5.0 & 3.654 & 1.0617 & 1.127 \\
Social Practices & 128 & 1.0 & 5.0 & 3.578 & .9102 & .828 \\
Influencers & 125 & 1.0 & 5.0 & 3.432 & 1.1732 & 1.376 \\
Valid N (listwise) & 124 & & & & & \\
\hline
\end{tabular}

respectively on a scale of 1 to 5 (1-least effective, 5- most

When the respondents are asked the key reason for following a effective). brand on social media, respondents selected Product Quality as the major factor with a mean of 3.992 followed by Logo \& Taglines and Advertisements with a mean of 3.654 and 3.608

3. Effectiveness of Marketing on various Social Platforms

\begin{tabular}{|c|c|c|c|c|c|c|}
\hline & $\mathrm{N}$ & Minimum & Maximum & Mean & $\begin{array}{l}\text { Std. } \\
\text { Deviation }\end{array}$ & Variance \\
\hline $\begin{array}{ll}\text { Effectiveness } & \text { of } \\
\text { Marketing } & \text { on } \\
\text { Facebook } & \end{array}$ & 151 & 1.0 & 5.0 & 3.570 & .9967 & .993 \\
\hline $\begin{array}{ll}\text { Effectiveness } & \text { of } \\
\text { Marketing } & \text { on } \\
\text { Instagram } & \end{array}$ & 151 & 1.0 & 5.0 & 4.417 & .8112 & .658 \\
\hline $\begin{array}{ll}\text { Effectiveness } & \text { of } \\
\text { Marketing } & \text { on } \\
\text { Snapchat } & \end{array}$ & 151 & 1.0 & 5.0 & 3.026 & .9930 & .986 \\
\hline $\begin{array}{ll}\text { Effectiveness } & \text { of } \\
\text { Marketing } & \text { on } \\
\text { Twitter } & \end{array}$ & 151 & 1.0 & 5.0 & 3.762 & .9571 & .916 \\
\hline
\end{tabular}




\begin{tabular}{|c|c|c|c|c|c|c|}
\hline $\begin{array}{l}\text { Effectiveness of } \\
\text { Marketing on } \\
\text { Other Platforms }\end{array}$ & 151 & 1.0 & 5.0 & 2.914 & 1.1072 & 1.226 \\
\hline Valid N (listwise) & 151 & & & & & \\
\hline
\end{tabular}

In answer to the question of selecting the best social marketing

average of 4.417, Twitter as No. 2 and Facebook ranked $3^{\text {rd }}$ on platform, respondents ranked Instagram as No. 1 with an

a scale of 1 to 5 (1-least effective, 5- most efficient).

\section{Impact of Social Media Marketing}

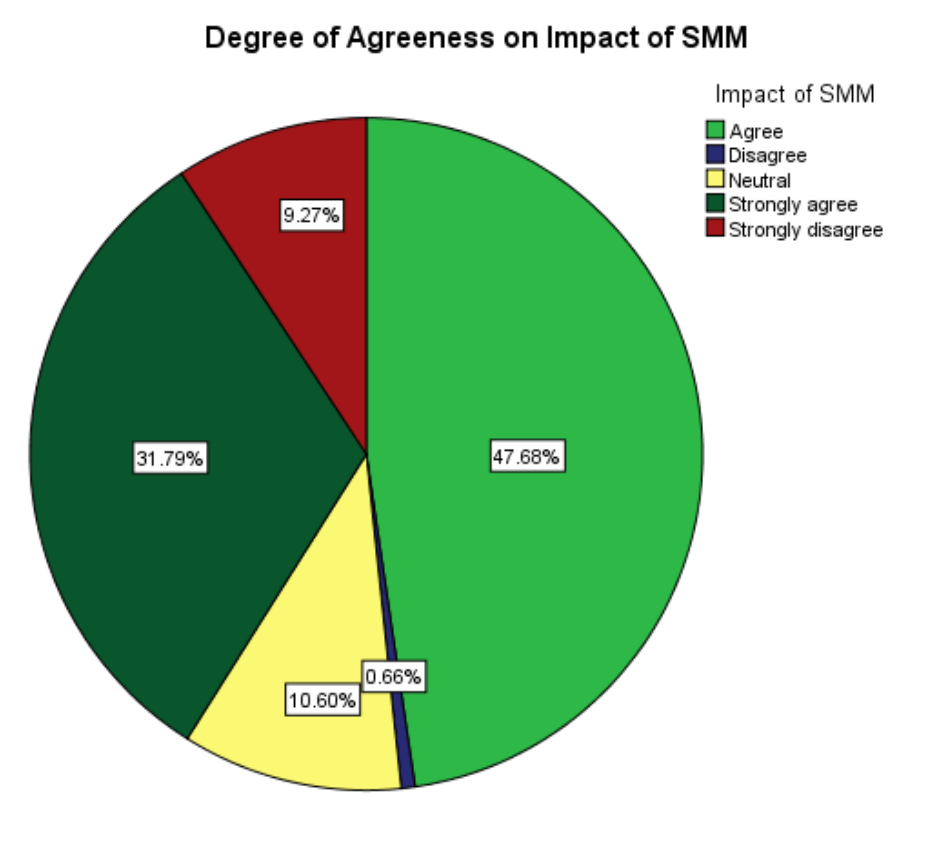

From the above pie chart, it is inferred that $31.79 \%$ strongly agreed out of 151 responses and $47.68 \%$ agreed that social media marketing among the millennial generation has a greater influence on brand image communication. $10.60 \%$ of the respondents stayed neutral, with just a small percentage of $9.93 \%$ of the total disagreeing with this.

\section{Key Findings}

* $90.9 \%$ of females and $89.6 \%$ of males chose Social media as a more effective form of marketing

* $91.3 \%$ of the responders who are aware of SMM chose Social Media Marketing as more impactful

* Out of the responders who are aware of SMM around $79 \%$ chose Social media platforms while $12.7 \%$ chose OTT platforms to be the better one for advertising while print media was the lowest category with $1.3 \%$

* Social media ads chose to be the most effective category followed by Influencers

* Users chose product quality as the 1st followed by Logo \& Taglines and
Advertisements as the major reason while following a brand on Social Media

* Out of 151 responses, people chose Instagram as the preferred platform for marketing followed by Twitter and Facebook in present times

* 136 respondents $(90.7 \%)$ believed that in today's world, Social Media channels have a leading impact on consumers as compared to Traditional media tools or any other methods

* About $66 \%$ of the surveyed people follow their favorite brand from the past 6 months or more on any social media platforms

* $79.5 \%$ of the surveyed people agreed that social media marketing methods are more efficient in communicating a brand image to millennials and gen $\mathrm{Z}$

A majority of respondents have agreed and according to them tools like Social Media networking sites, OTT platforms, internet, and digital marketing techniques are the need of the hour. For targeting the young generation, that is more active on digital platforms than physical brands have to come and promote themselves on social media and other platforms to improve their brand image and awareness. Hence from the 
responses and chi-square test results, we can say that Social Media Marketing is more effective in communicating brand image than Traditional Marketing in the Indian young generation.

\section{Scope of the study}

As only millennials and centennials spend their maximum time on social media, hence I have kept the scope of my study limited to them. The preferences of social media platforms and behavior of other countries are different from Indians and it is difficult to study all, so the scope will be limited to only those Indian customers who follow at least one brand on social media.

As of 2019, India has about 574 million active Internet users and this number is expected to cross the 639 million mark by December 2020. Out of this huge internet-using population, $67 \%$ falls under the age bracket of 12-29 years.

(Source: Internet \& Mobile Association of India (IAMAI), GlobalWebIndex)

Around $54 \%$ of Indian Internet user base was between the ages of 20 and 39 in early 2019. People above 40 years formed the lowest share, while teenagers in the range of 12 to 15 years form a good 14 percent share of the total internet consumer base.

India has around 326 million social media users in 2018. IPL, one of the most famous cricketing event followed religiously in India, had the highest user's presence amongst all cricket events globally. The IPL teams registered more than fifty-nine million likes on Facebook only and above eighty-one million followers on Twitter. Out of these likes \& followers, the maximum Facebook usage came from the millennials in the age group of 18-24 years with around ninety-seven million users in 2018. Hence, the reason for the limited scope of the study to only millennials and centennials.

\section{Conclusion}

Results have indicated that social media marketing is the go-to area for marketers targeting the young generation like gen $Y$ and $\mathrm{Z}$ consumers. Findings will help marketers and practitioners devise strategies to build and maintain a positive brand image. This will further strengthen their brand value to achieve competitive advantage and business sustainability, particularly among young consumer markets. Empirically, marketers and practitioners should make use of technology in social networking sites such as Facebook, Instagram, etc. to enhance young consumers' brand recognition by providing innovative and insightful product ads and content that could encourage their purchasing intention. It is worth noting that a firm with a strong brand image is gaining a stronger market position and can maintain a competitive advantage, in the long run, to further grow its market share. According to (Norazah, 2013b) young consumers especially in the 15-30 age group strongly and actively use information when evaluating products during purchasing decisions and this knowledge can be provided to them with the help of social media tools and platforms. Various studies have already been done in the past related to this area in other countries like Iceland, Spain, USA, Russia, etc. and the key findings of those are similar to this study.

\section{Limitations}

While conducting the research and data collection following limitations are there:

- Only the Indian population has taken into account while conducting the survey

- The study covers a survey of only 151 respondents. Hence, we admit that the sample size is very small as compared to the total population

- Samples from only millennials \& gen $\mathrm{Z}$ or centennials were taken for doing analysis

- Only responses from customers who are on any social media platform and follow at least one brand on it are recorded

\section{References}

[1]. 1989-, A. (2014, May 15). Effect of Social Media Marketing on Traditional Marketing Campaigns in Young Icelandic Companies. Retrieved from https://skemman.is/handle/1946/18659

[2]. Bhasin, H. (2020, July 11). Traditional Marketing: What is Traditional Marketing? Retrieved from https://www.marketing91.com/traditionalmarketing/

[3]. Bruhn, M., Schoenmueller, V., \& Schäfer, D. (2012, August 03). Are social media replacing traditional media in terms of brand equity creation? Retrieved from

https://www.emerald.com/insight/content/doi/10.11 08/01409171211255948/full/html

[4]. Digital Trends 2019 \& Social Media Landscape in India. (2020, August 25). Retrieved from https://sannams4.com/digital-and-social-medialandscape-in-india/

[5]. http://www.divaportal.org/smash/get/diva2:121411/FULLTEXT 01.pdf

[6]. https://www.theseus.fi/bitstream/handle/100 24/46954/Nekatibeb_Tesfaye.pdf?sequence= 1

[7]. https://www.theseus.fi/bitstream/handle/100 24/105658/Jokinen_Tomi.pdf?sequence=1

[8]. http://www.ijimt.org/vol7/643-M738.pdf

[9]. http://blog.mahanbs.com/Images/Weblog/blo g/Webl 
ogHtmlFile/1-s2.0-S0007681314000949main.pdf

[10]. https://www.ssoar.info/ssoar/bitstream/handl e/document/67069/ssoar-jthsm-2017-2chatzigeorgiou

Modelling_the_impact_of_social.pdf?sequenc e=1\&isAllowed=y\&Inkname=ssoar-jthsm2017-2-chatzigeorgiouModelling_the_impact_of_social.pdf

[11]. Keelery, P., \& 7, J. (2020, July 07). Social media users in India. Retrieved from https://www.statista.com/statistics/278407/numberof-social-network-users-in-india/

[12]. Kemp, S. (2020, February 18). Digital 2020: India DataReportal - Global Digital Insights. Retrieved from https://datareportal.com/reports/digital-2020india

[13]. Lang, B. (2016, May 03). Social Media vs. Traditional Media - Make the Transition. Retrieved from https://uhurunetwork.com/social-media-vstraditional-media/

[14]. Mnet1cyber. (n.d.). However an individuals prior conditions may lead to selective exposure or: Course Hero. Retrieved from https://www.coursehero.com/file/pmb0rp/Howeveran-individuals-prior-conditions-may-lead-toselective-exposure-or/

[15]. Pti. (2019, March 06). Internet users in India to reach 627 million in 2019: Report. Retrieved from https://economictimes.indiatimes.com/tech/internet/ internet-users-in-india-to-reach-627-million-in2019-report/articleshow/68288868.cms

[16]. Shiram, M. (2017, October 13). Traditional marketing vs. digital marketing. Retrieved from https://yourstory.com/mystory/e09309421ctraditional-marketing

[17]. Sivakumar, B., Pandey, M., Pandey, A., Popli, C., Pahwa, A., \& Ahuja, Y. (2020, August 25). Business Models \& Startup Feeds. Retrieved from https://www.feedough.com/

[18]. Soni, Y., \& Staff, I. (2019, June 12). India Second In The Number Of Internet Users With 12\% Of Global Users: Mary Meeker. Retrieved from https://inc42.com/buzz/india-second-in-number-ofinternet-users-mary-meeker/

[19]. Traditional Marketing: What is Traditional Marketing? (n.d.). Retrieved from https://www.marketing-schools.org/types-ofmarketing/traditional-marketing.html

[20]. What is Social Media Marketing? (n.d.). Retrieved from https://buffer.com/social-media-marketing
[21]. Chatzigeorgiou, C. (2017). Modelling the impact of social media influencers on behavioural intentions of millennials: The case of tourism in rural areas in Greece. Journal of Tourism, Heritage \& Services Marketing, 3(2), 25-29

[22]. Cowden, A. G. (2014). Effect of social media marketing on traditional marketing campaigns in young Icelandic companies (Doctoral dissertation)

[23]. D'silva, B., Bhuptani, R., Menon, S., \& D'Silva, S. (2011, March). Influence of social media marketing on brand choice behaviour among youth in India: an empirical study. In International Conference on Technology and Business Management (pp. 28-30)

[24]. Duffett, R. G. (2017). Influence of social media marketing communications on young consumers' attitudes. Young Consumers

[25]. Erdoğmuş, İ. E., \& Cicek, M. (2012). The impact of social media marketing on brand loyalty. ProcediaSocial and Behavioral Sciences, 58, 1353-1360

[26]. Hanaysha, J. (2016). The importance of social media advertisements in enhancing brand equity: A study on the fast-food restaurant industry in Malaysia. International Journal of Innovation, Management and Technology, 7(2), 46

[27]. Ivanov, A. E. (2012). The Internet's impact on integrated marketing communication. Procedia Economics and Finance, 3, 536-542

[28]. Jokinen, T. (2016). Branding in Social Media and the Impact of Social Media on Brand Image

[29]. Nekatibeb, T. (2012). Evaluating the impact of social media on traditional marketing

[30]. Suki, J. S. N. M., \& Sasmita, J. (2015). Young consumers' insights on brand equity: Effects of brand association, brand loyalty, brand awareness, and brand image. International Journal of Retail \& Distribution Management, 43(3), 276-292

[31]. Tiago, M. T. P. M. B., \& Veríssimo, J. M. C. (2014). Digital marketing and social media: Why bother?. Business horizons, 57(6), 703-708

[32]. Varfan, M., \& Shima, A. (2008). Traditional marketing vs. Internet marketing. A comparison 